\title{
Mongolian Short-toed Lark Calandrella dukhunensis, an overlooked East Asian species
}

\author{
Per Alström ${ }^{1,2}$ (D) Gombobaatar Sundev ${ }^{3}$
}

Received: 6 May 2020 / Revised: 27 August 2020 / Accepted: 8 September 2020 / Published online: 23 September 2020

(c) The Author(s) 2020

\begin{abstract}
The eastern subspecies of Greater Short-toed Lark Calandrella brachydactyla dukhunensis has recently been considered a separate species, Calandrella dukhunensis, by several authors based on molecular data. We present supporting evidence for this treatment based on studies of morphology, vocalisations and song-flight, and also present new data on other aspects of its biology based on field studies. We show that its breeding distribution is considerably smaller than previously thought, and is restricted to the eastern half of Mongolia and, marginally, neighbouring parts of China and perhaps Russia.
\end{abstract}

Keywords Calandrella brachydactyla Taxonomy

\section{Zusammenfassung}

\section{Die Chinalerche Calandrella dukhunensis, eine übersehene ostasiatische Art}

Die östliche Unterart der Kurzzehenlerche Calandrella brachydactyla dukhunensis wird seit kurzem von mehreren Autoren auf Basis molekularer Daten als eigene Art, Calandrella dukhunensis, betrachtet. Wir legen hier zusätzliche Belege für diese Einstufung vor. Diese beruhen auf Untersuchungen zur Morphologie, Vokalisation und des Singfluges. Basierend auf Feldstudien präsentieren wir auch neue Daten über andere Aspekte der Biologie dieser Art. Wir zeigen, dass das Brutgebiet wesentlich kleiner ist, als bisher angenommen und sich auf die östliche Hälfte der Mongolei und kleine Teile des benachbarten Chinas und eventuell Russlands beschränkt.

Communicated by J. T. Lifjeld.

Electronic supplementary material The online version of this article (https://doi.org/10.1007/s10336-020-01819-z) contains supplementary material, which is available to authorized users.

Per Alström

per.alstrom@ebc.uu.se

1 Animal Ecology, Department of Ecology and Genetics, Evolutionary Biology Centre, Uppsala University, Norbyvägen 18D, 75236 Uppsala, Sweden

2 Key Laboratory of Zoological Systematics and Evolution, Institute of Zoology, Chinese Academy of Sciences, Beijing 100101, China

3 National University of Mongolia and Mongolian Ornithological Society, Ulaanbaatar 210646a, P.O. Box 537, Ulaanbaatar, Mongolia

\section{Introduction}

The Greater Short-toed Lark Calandrella brachydactyla was previously considered conspecific with Red-capped Lark $C$. cinerea, under that name (e.g. Meinertzhagen 1951; Vaurie 1959; Peters 1960), but was later suggested to be specifically different (reviewed in Stervander et al. 2016). Calandrella brachydactyla was considered to breed from northwest Africa and the Iberian Peninsula through southern Europe and western and central Asia to northeastern Mongolia and adjacent parts of Russia and China, and across the eastern part of the Tibetan Plateau to just north of the Himalayas, and to winter locally in northwestern Africa, but mainly in the Sahel region of Africa and the Arabian Peninsula east to India (Glutz von Blotzheim and Bauer 1985; Cramp 1988; Sibley and Monroe 1990; de Juana and Suárez 2004; Dickinson and Christidis 2014; Christidis 2018). Most authors recognised 6-9 subspecies.

Alström et al. (2013) found, based on the mitochondrial cytochrome $b$ gene, that the eastern subspecies, $C$. $b$. 
dukhunensis, was more closely related to Hume's Lark $C$. acutirostris than to other populations of $C$. brachydactyla (as well as $C$. cinerea). This was corroborated by Stervander et al. (2016) based on genomic data for the same single $C$. b. dukhunensis sample analysed by Alström et al. (2013), collected on the breeding grounds in eastern Mongolia, as well as cytochrome $b$ sequence data from five additional $C$. $b$. dukhunensis collected in the winter quarters in central and northeast India. The divergence time between western taxa of $C$. brachydactyla and C. b. dukhunensis plus $C$. acutirostris was estimated at 6.0 million years ago (mya) by Alström et al. (2013) and c. 5 mya by Stervander et al. (2016), although their confidence intervals for the dates were broadly overlapping.

The results from the phylogenetic analyses have led some recent authors to recognise $C$. dukhunensis as a distinct species, with the English name Sykes's Short-toed Lark (Clements et al. 2019), Mongolian Short-toed Lark (Shirihai and Svensson 2018; Gill et al. 2020) or Eastern Short-toed Lark (del Hoyo and Collar 2016; del Hoyo et al. 2020). However, there is no consensus among these authors regarding its breeding range. According to Clements et al. (2019), it breeds in "north central China (central and eastern Xinjiang) south to Tibet"; according to Shirihai and Svensson (2018) "Tibetan plateau, and through E Xinjiang and S and E Mongolia to E Transbaikalia and W Manchuria"; according to Gill et al. (2020) in west and central China; and according to del Hoyo and Collar (2016) and del Hoyo et al. (2020) "Tibet, central and northeastern China, the eastern half of Mongolia and Transbaikalia". The distribution in northern Mongolia, northeastern China and Transbaikalia given by del Hoyo and Collar (2016) and del Hoyo et al. (2020) is inhabited by $C$. brachydactyla according to the other authors, whereas the eastern limit of $C$. brachydactyla is in west Mongolia according to del Hoyo and Collar (2016) and del Hoyo et al. (2020). It is surprising that neither Clements et al. (2019) nor Gill et al. (2020) include Mongolia in the range of $C$. dukhunensis as the single breeding period sample of this taxon that was included in the phylogenetic analyses that form the basis for the recognition of C. dukhunensis as a distinct species (Alström et al. 2013; Stervander et al. 2016) was collected in eastern Mongolia. Moreover, neither Christidis (2018), Shirihai and Svensson (2018), Clements et al. (2019), Gill et al. (2020), del Hoyo and Collar (2016) nor del Hoyo et al. (2020) appear to have noted that Stervander et al. (2016) suggested that this complex does not breed at all on the Tibetan Plateau.

As the recently recognised species Calandrella dukhunensis is extremely poorly known in most respects, with much conflicting information in the literature on its distribution, and with the recent elevation to species rank resting solely on molecular evidence, we here describe the morphology, moult, breeding distribution, breeding habitat, vocalisations, song-flight, breeding, and migration period of this species based on field work and studies of museum specimens.

\section{Materials and methods}

Throughout, we treat Calandrella dukhunensis as a separate species from $C$. brachydactyla, based on the phylogenetic analyses by Alström et al. (2013) and Stervander et al. (2016). For subspecies taxonomy of $C$. brachydactyla, we follow del Hoyo et al. (2020). G.S. has studied C. dukhunensis in Mongolia on multiple occasions during 2005-2019, together with P.A. in mid-June 2016. P.A. has also observed this species multiple times on spring and autumn migration in China, and has examined specimens in the American Museum of Natural History, New York, USA (AMNH); University of Michigan Museum of Zoology, Ann Arbor, USA (UMMZ); Natural History Museum, Tring, UK (NHM); National Zoological Museum of China, Institute of Zoology, Chinese Academy of Sciences, Beijing (NZMC-IOZ); and Yamashina Institute of Ornithology, Chiba, Japan (YIO; on loan). In addition, P.A. has studied $C$. brachydactyla at multiple places throughout its breeding distribution (e.g. Morocco, Kazakhstan, northwest China) and on migration and in winter at multiple places (e.g. northwest India), as well as in the above and other museum collections (e.g. University of Copenhagen Zoological Museum, Denmark; ZMUK). Plumage comparisons were made by directly comparing museum specimens collected at the same time of the year, in comparable plumage and state of wear; plumage differences were only evaluated by eye, not by e.g. spectrophotometry. Measurements were taken by P.A. in the AMNH, ZMUC and UMMZ: wing length (with a ruler, wing flattened and stretched), tail length (with a ruler inserted under the undertail-coverts) and bill length (with calipers, to base of skull). Wing and tail lengths were measured to the nearest $0.5 \mathrm{~mm}$, whereas bill length was measured to the nearest $0.1 \mathrm{~mm}$.

To quantify differences in song between $C$. dukhunensis and $C$. brachydactyla, we analysed 8 high-quality recordings of songs of $C$. dukhunensis and 24 recordings of songs of $C$. brachydactyla, C. b. rubiginosa from Morocco (6); C. b. brachydactyla from Spain (3), France (2) and Italy (3); and C. b. longipennis from Kazakhstan (5) and Xinjiang Province, China (5), i.e. eight $C$. dukhunensis and 6-10 of each of three additional subspecies, all different individuals (Supplementary Table S1; all new recordings uploaded to Macaulay Library, Cornell University: https://www.macaulaylibrary.org). Sonograms were created in Raven Pro 1.5 (Cornell Lab of Ornithology, USA), with the following settings: Window size $=256$ samples; window type $=$ Hann; $3 \mathrm{~dB}$ filter bandwidth $=270 \mathrm{~Hz}$; overlap $=50 \%$; size $=2.67 \mathrm{~ms}$; DFT size $=256$ samples; 
spacing $=188 \mathrm{~Hz}$. The contrast was kept fixed at 93, and brightness was adjusted manually for each recording to give a good visual separation between the different song elements and the background noise. The following variables were measured for each song strophe (Fig. 1): Duration, Minimum Frequency, Maximum Frequency, Bandwidth, Peak Frequency (the frequency associated with the maximum energy) and the duration of Pauses between strophes. In addition, the number of 'notes' ('syllables' or single elements when given singly; Fig. 1) and the number of repetitions of a note in a sequence within a strophe was counted (up to four sequences with repetitions were observed; a sequence of notes was treated as a repeat also if the notes gradually changed appearance due to, e.g., a gradual change of pitch; Fig. 1). Ten unique strophes per song were measured, or all of the strophes if fewer than ten (in total $>300$ unique strophes). All measurements were taken by the same person (P.A.). In addition to measurements, the sonograms were compared by eye and the recordings compared by ear. Additional sound recordings were listened to, but not included in the analyses, including sound recordings available on Macaulay Library and xeno-canto (https://xeno-canto.org) and own sound recordings (in total c. 15 C. dukhunensis and c. 100 C. brachydactyla). As the song of $C$. dukhunensis is not divided into strophes with pauses between (see Results) to produce comparable measurements of the above variables (except pauses) we took measurements of $C$. dukhunensis songs from sequences of continuous song that corresponded to the mean value of the strophe length in C. brachydactyla, separated by the mean value of pause length in $C$. brachydactyla (Fig. 2).

Calls of multiple $C$. dukhunensis $(\geq 100)$ and C. brachydactyla ("hundreds") from the areas mentioned above have been heard in the field by us, and some sound recorded by us, and additional recordings of $C$. brachydactyla have also been listened to at Macaulay Library and xeno-canto. Sound recordings have been compared by ear and by eye on songrams.
Fig. 1 Sound terminology. Calandrella brachydactyla rubiginosa, Morocco (ML274004, Per Alström)
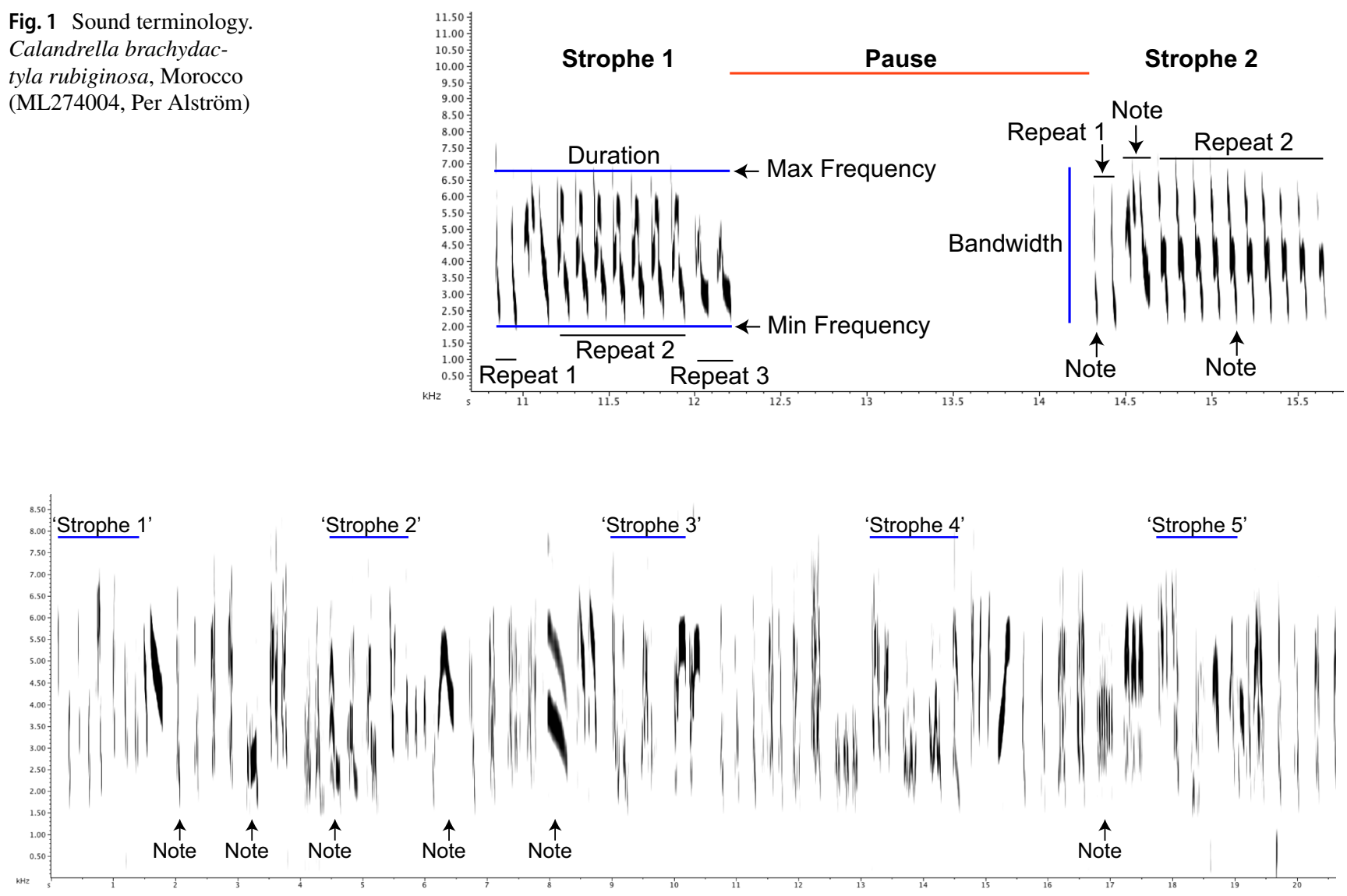

Fig. 2 Artifical delimitation of 'strophes' in Calandrella dukhunensis (based on approximate mean value of strophe duration and pause length in C. brachydactyla) for measurements. A few notes indicated. Terminology otherwise as in Fig. 1. Mongolia (ML274027, Per Alström) 


\section{Results}

\section{Morphology and moult}

Compared to the most easterly breeding subspecies of $C$. brachydactyla, C. b. longipennis, the upperside of $C$. dukhunensis is slightly darker and browner (though can be indistinguishable from $C$. b. longipennis); the breast (at least on the sides) and flanks are much warmer in colour, rufous-buffish, contrasting with the upperside (buff on flanks often mainly concealed under wings); and the belly and undertail-coverts are pale buffish-tinged when fresh (whiter in C. b. longipennis). The upperside is not so rufous-tinged as in typical $C$. $b$. brachydactyla in fresh plumage, whereas the buffish colour on the breast is on average deeper and more extensive than in $C$. b. brachydactyla. The forehead and crown are usually concolorous with the upperparts or only slightly more rufous-tinged in $C$. dukhunensis, as in C. b. longipennis, but unlike many $C$. brachydactyla of other subspecies in which the forehead/crown are more contrastingly rufous than the upperparts (almost 100\% in C. b. rubiginosa and c. $85 \%$ in C. b. brachydactyla according to Vaurie 1959). In worn plumage, the forehead and crown of $C$. dukhunensis are usually very faintly streaked, especially on the forehead and anterior part of the crown, unlike in nearly all $C . b$. longipennis, though many $C . b$. brachydactyla are similar. In all taxa, the colours are warmer in fresh than in worn plumage, so comparisons are only valid for individuals at similar stage of wear. The bill is pale greyish pink (rarely more pinkish grey) with a medium or dark grey culmen, similar to that of $C$. brachydactyla, though the culmen averages darker, and the tip of the lower mandible is more frequently dark (in both ways approaching $C$. acutirostris; P.A. pers. obs.). The tarsi and toes are pale pink and the claws are medium grey; the legs/toes are not dark (contra Colston and Shirihai 1986; Hollom et al. 1988; Porter et al. 1996). See Fig. 3 for examples of $C$. dukhunensis and $C$. b. longipennis. Calandrella dukhunensis has a significantly longer wing, and males also have a significantly longer tail, than C. brachydactyla (Table 1).

Juvenile $C$. dukhunensis (Fig. 4a, b) is markedly different from adult in showing paler centres with dark subterminal bands to the feathers above, wings and central rectrices, and pale fringes, especially tips, to the feathers above, giving a
Fig. 3 Calandrella dukhunen$\operatorname{sis}(\mathbf{a}, \mathbf{b}, \mathbf{e}, \mathbf{f})$ and C. brachydactyla longipennis $(\mathbf{c}, \mathbf{d})$. a Calandrella dukhunensis adult, Yingkou, Liaoning Prov., China, 3 June 2018 (Chengyi Liu). b C. dukhunensis adult, Uulbayan sum, Sukhbaatar Prov., Mongolia, 22 May 2011 (Gombobaatar Sundev). c $C$. $b$. longipennis adult, Rajasthan, India, February 2019 (Paul F. Donald). d $C$. b. longipennis adult, Xinjiang, China, 15 May 2018 (Jonathan Martinez/Tragopan). This bird is unusual in that it has replaced one tertial. e C. dukhunensis which has almost completed the post-juvenile moult [a few juvenile feathers not yet replaced, e.g. inner median covert (other median coverts missing) and inner secondary], Khalzan sum, Sukhbaatar Prov., Mongolia, 20 August 2011 (Gombobaatar Sundev). f C. dukhunensis freshly moulted (probably not quite completed) Khalzan sum, Sukhbaatar Prov., Mongolia, 20 August 2011 (Gombobaatar Sundev)

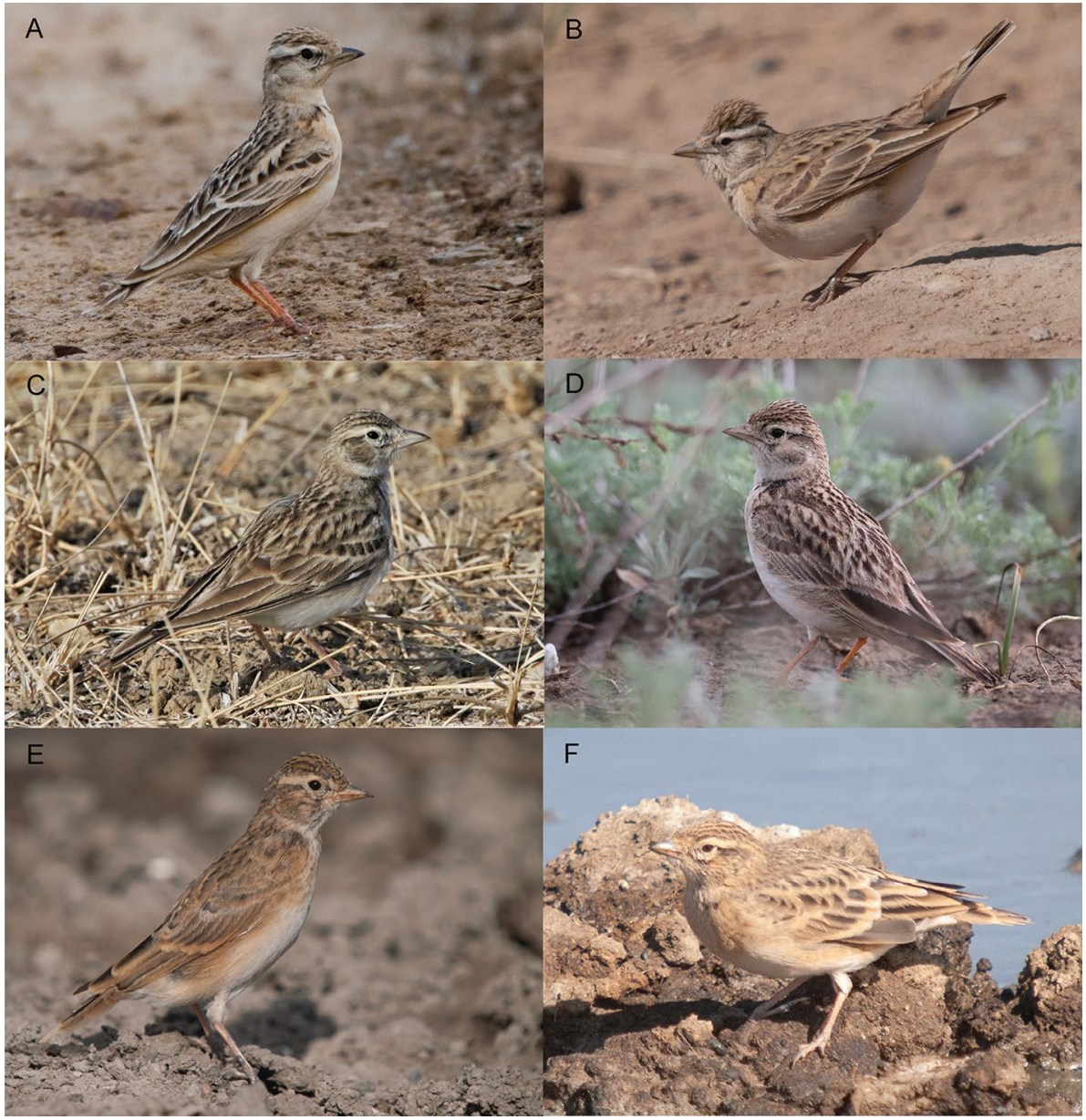


Table 1 Morphometrics of C. brachydactyla and $C$. dukhunensis

Fig. 4 a, b Calandrella dukhunensis juveniles, Menen Steppe and Buir Lake, Dornod Prov., Mongolia, 20 July 2009 (Gombobaatar Sundev). c Nest with eggs of C. dukhunensis Darkhan area, Darkhan sum, Hentii Prov., Mongolia, 4 June 2006 (Gombobaatar Sundev). d Nest with nestlings of $C$. dukhunensis Bayan-Ovoo sum, Hentii Prov., Mongolia, 17 June2016 (Gombobaatar Sundev). Habitats of C. dukhunensis Darkhan area, Hentii Prov., Mongolia, June 2006 (e) and Bayan-Ovoo sum, Hentii Prov., Mongolia, 17 June 2016 (f) (Gombobaatar Sundev)

\begin{tabular}{|c|c|c|c|c|}
\hline Taxon & Area & Wing length & Tail length & Bill length \\
\hline \multicolumn{5}{|l|}{ Males } \\
\hline C. b. rubiginosa & Morocco, Algeria & $94.9( \pm 1.40 ; 10)$ & $57.5( \pm 1.50 ; 10)$ & $14.5( \pm 0.19 ; 10)$ \\
\hline C. b. brachydactyla & Europe & $95.5( \pm 2.73 ; 17)$ & $59.1( \pm 2.42 ; 17)$ & $13.9( \pm 0.52 ; 17)$ \\
\hline C. b. hermonensis & 'Palestine', Lebanon & $94.7( \pm 2.93 ; 10)$ & $57.2( \pm 2.90 ; 10)$ & $13.4( \pm 0.71 ; 10)$ \\
\hline C. b. artemisiana & Lorestan, Iran & $95.6( \pm 3.66 ; 13)$ & $55.5( \pm 4.56 ; 13)$ & $14.0( \pm 0.79 ; 13)$ \\
\hline C. b. longipennis & Afghanistan & $95.4( \pm 2.08 ; 18)$ & $57.6( \pm 1.75 ; 18)$ & $13.4( \pm 0.59 ; 18)$ \\
\hline All C. brachydactyla & & $95.3( \pm 2.61 ; 68)$ & $57.5( \pm 2.96 ; 68)$ & $13.8( \pm 0.70 ; 68)$ \\
\hline C. dukhunensis & India (winter) & $100.4( \pm 1.92 ; 10)$ & $58.8( \pm 1.30 ; 10)$ & $13.7( \pm 0.48 ; 10)$ \\
\hline \multicolumn{5}{|l|}{ Females } \\
\hline C. b. rubiginosa & Morocco, Algeria & $89.4( \pm 1.75 ; 4)$ & $53.1( \pm 1.44 ; 4)$ & $13.8( \pm 0.48 ; 4)$ \\
\hline C. b. brachydactyla & Europe & $89.7( \pm 3.52 ; 12)$ & $53.0( \pm 2.44 ; 12)$ & $13.5( \pm 0.45 ; 12)$ \\
\hline C. b. hermonensis & 'Palestine', Lebanon & $90.6( \pm 3.47 ; 4)$ & $52.9( \pm 0.95 ; 4)$ & $12.8( \pm 0.36 ; 4)$ \\
\hline C. b. artemisiana & Lorestan, Iran & $90.8( \pm 0.35 ; 2)$ & $53.5( \pm 1.41 ; 2)$ & $14.3( \pm 1.63 ; 2)$ \\
\hline C. b. longipennis & Afghanistan & $87.8( \pm 1.60 ; 7)$ & $51.4( \pm 1.35 ; 7)$ & $13.4( \pm 0.54 ; 7)$ \\
\hline All C. brachydactyla & & $89.4( \pm 2.84 ; 29)$ & $52.6( \pm 1.92 ; 29)$ & $13.5( \pm 0.64 ; 29)$ \\
\hline C. dukhunensis & India & $94.0( \pm 2.00 ; 10)$ & $51.9( \pm 2.43 ; 10)$ & $13.2( \pm 0.54 ; 10)$ \\
\hline
\end{tabular}

All measurements in millimeters. Numbers in brackets are standard deviation and sample size. Wing length significantly different between all $C$. brachydactyla combined and $C$. dukhunensis for both males and females $(P=0.000)$ and for tail length for males $(P=0.025)$

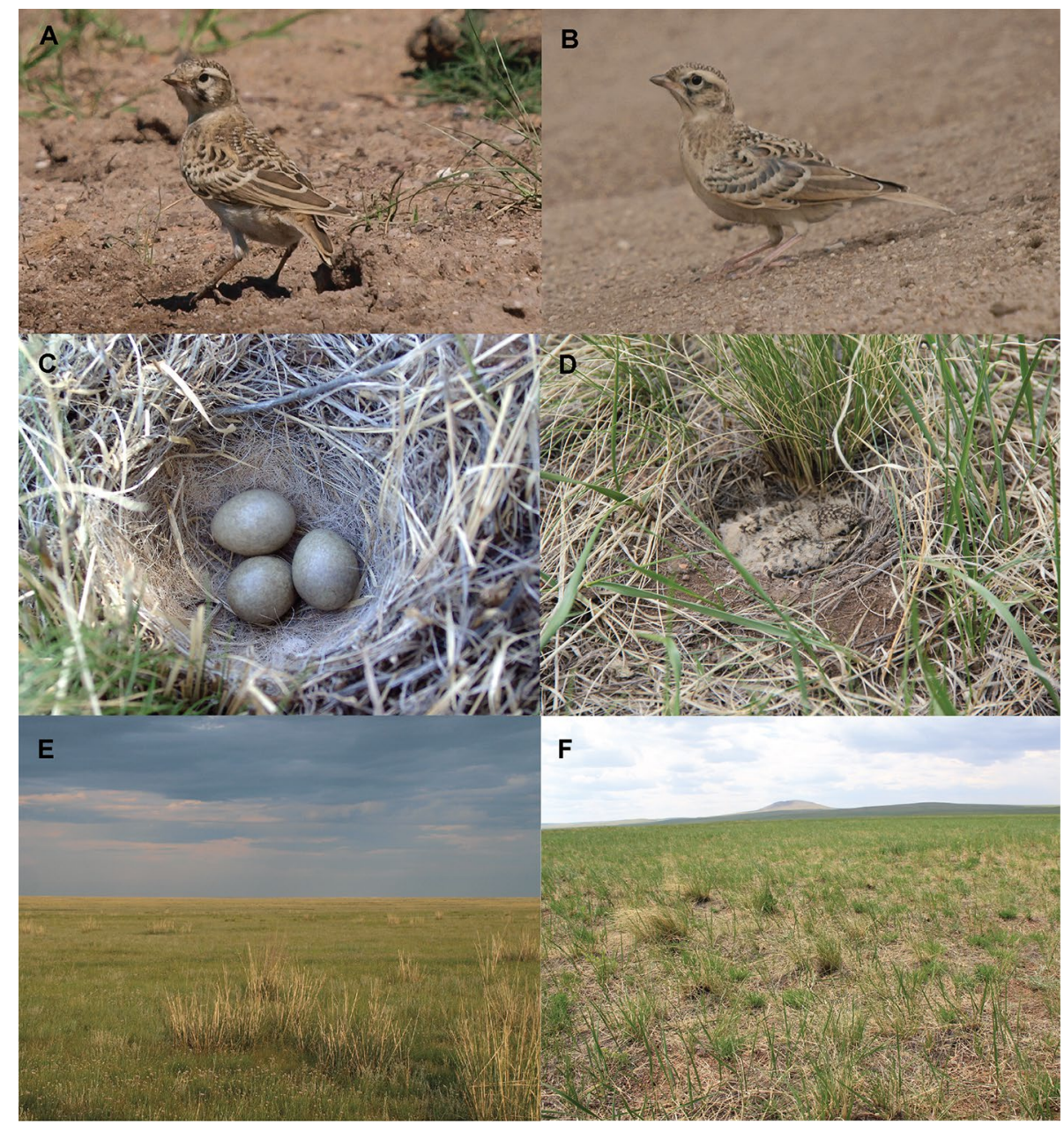


scaly or pale-spotted appearance. The breast is lightly darkspotted, without the dark patch on the side usually shown by adults. We have not noted any differences compared to juvenile $C$. brachydactyla.

Unlike $C$. brachydactyla, $C$. dukhunensis has a partial pre-breeding moult, which takes place in January to March, and which includes at least some head and body feathers and often some secondary coverts and tertials. A few $C$. $b$. brachydactyla and $C$. b. longipennis moult crown-feathers, and at least a few birds from Morocco (C. b. rubiginosa) renew feathers on the crown, sides of the breast and mantle; the odd secondary covert and tertial are only exceptionally replaced. The complete adult post-breeding moult of $C . d u k$ hunensis appears to take place mainly in August, and we have seen adults that have almost finished moulting on 20 August. One specimen (IZH-V 0697) from Manzhouli, Nei Menggu Province, China has almost finished the complete moult (Frank Steinheimer, in litt.). We have observed birds in full juvenile plumage as late as 20 July, and birds in active post-juvenile moult between 27 June (recently started) and 20 August (nearly finished complete moult).

\section{Song and song-flight}

The song of C. dukhunensis (Figs. 2, 5, 6, Table 2, Supplementary Table $\mathrm{S} 1$ ) is a continuous quick-paced ramble of notes of varying pitch, duration and quality, including whistles and short clicking notes, and imitations of other birds (e.g. Red-wattled Lapwing Vanellus indicus, apparently learnt in the winter quarters, as this species does not occur in or near Mongolia). The notes are often repeated several times, frequently as fast rattles. The repertoire of notes is very large (no attempt has been made at quantifying this). In our sample, the song continued for up to c. $6 \mathrm{~min}$.
In contrast, the song of $C$. brachydactyla (Figs. 1, 5 . 6 , Table 2, Supplementary Table S1) is delivered in short (0.6-2.0 s; mean $1.2 \mathrm{~s} \pm 0.2 \mathrm{~s} . d$.) $)$ strophes with marked pauses $(0.4-5.2 \mathrm{~s}$; mean $2.9 \mathrm{~s} \pm 0.8 \mathrm{~s} . \mathrm{d}$.) between the strophes. Moreover, the song is faster than in $C$. dukhunensis as the notes are given at shorter intervals (7-25 notes/strophe; mean $12.6 \pm 3.0$ s.d.; as opposed to $2-9$ notes/strophe; mean $6.1 \pm 1.5$ s.d. in $C$. dukhunensis; see Materials and methods and Fig. 2 how this value was calculated, as $C$. dukhunensis has no well-defined strophes). Moreover, the minimum frequency averages higher and the maximum frequency lower, and accordingly the frequency span averages narrower in $C$. brachydactyla than in C. dukhunensis; the peak frequency is also lower on average in $C$. brachydactyla. The repertoire of strophes is large, and identical strophes are only rarely given in a single song (no attempts at quantifying these variables). In our sample, the song of $C$. brachydactyla continued for up to c. $6.5 \mathrm{~min}$.

We noted some average differences between different populations of $C$. brachydactyla. This was most notable with respect to the proportion of song strophes with repeated notes, which gradually declined from $100 \%$ in Morocco to $14 \%$ in Xinjiang (Table 2, Supplementary Table S1). The songs of Moroccan birds sound decidedly rattling due to the many repetitions.

The song of $C$. dukhunensis is delivered in a song-flight. The bird rises while singing, with rather quick wing-beats and slightly fanned tail, and then flies around in irregular 'circles' with persistently beating wings; at the peak of the flight, the wing-beats may slow down a little. The bird either plunges silently to the ground from the peak elevation or ascends somewhat before the final silent plunge to the ground. A video of one song-flight is viewable at https ://www.macaulaylibrary.org (ML488776). We have also
Fig. 5 Songs of Calandrella dukhunensis (top: Hentii Prov., Mongolia, 18 June 2016; ML274025) and C. brachydactyla longipennis (bottom: Kazakhstan, May 2006; ML274010), both in high songflight, to show continuous song in C. dukhunensis and short strophes separated by longer pauses in C. brachydactyla. Both recordings by Per Alström

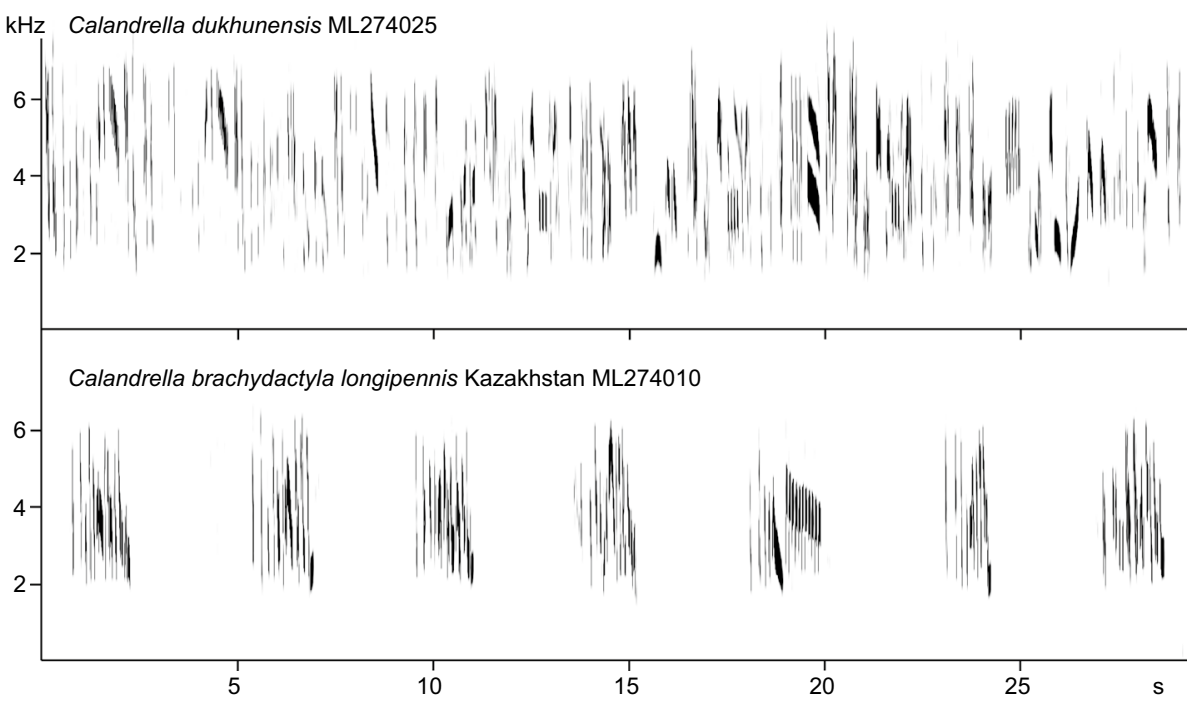


Fig. 6 Sonograms of song in high song-flight of Calandrella dukhunensis and C. brachydactyla. C. dukhunensis ML274022 (continuous song on two rows), Hentii Prov., Mongolia, 18 June 2016 (Per Alström); $C$. dukhunensis ML274026, Hentii Prov., Mongolia, 18 June 2016 (Per Alström); C. b. longipennis ML274016, Xinjiang Province, China, May 2018 (Per Alström); C. b. longipennis XC120521, Shygan, Kazakhstan, May 2011 (Patrick Franke); C. b. longipennis XC145088, Korgalzhyn,

Akmola, Kazakhstan, May 2011 (Thijs Fijen); $C$. b. brachydactyla XC295988, Toscana, Italy, June 2014 (Marco Dragonetti); C. b. brachydactyla XC206247, Catalonia, Spain, June 2012 (Jordi Calvet); C. b. rubiginosa ML274005, Tazenakht, Morocco, April 1989 (Per Alström). Pauses between strophes of C. brachydactyla have been artificially shortened (indicated by blue dashed vertical bars). See Figs. 1 and 2 for sonograms of two additional individuals (Fig. 2 at a different scale on the time axis). All sonograms refer to different individuals

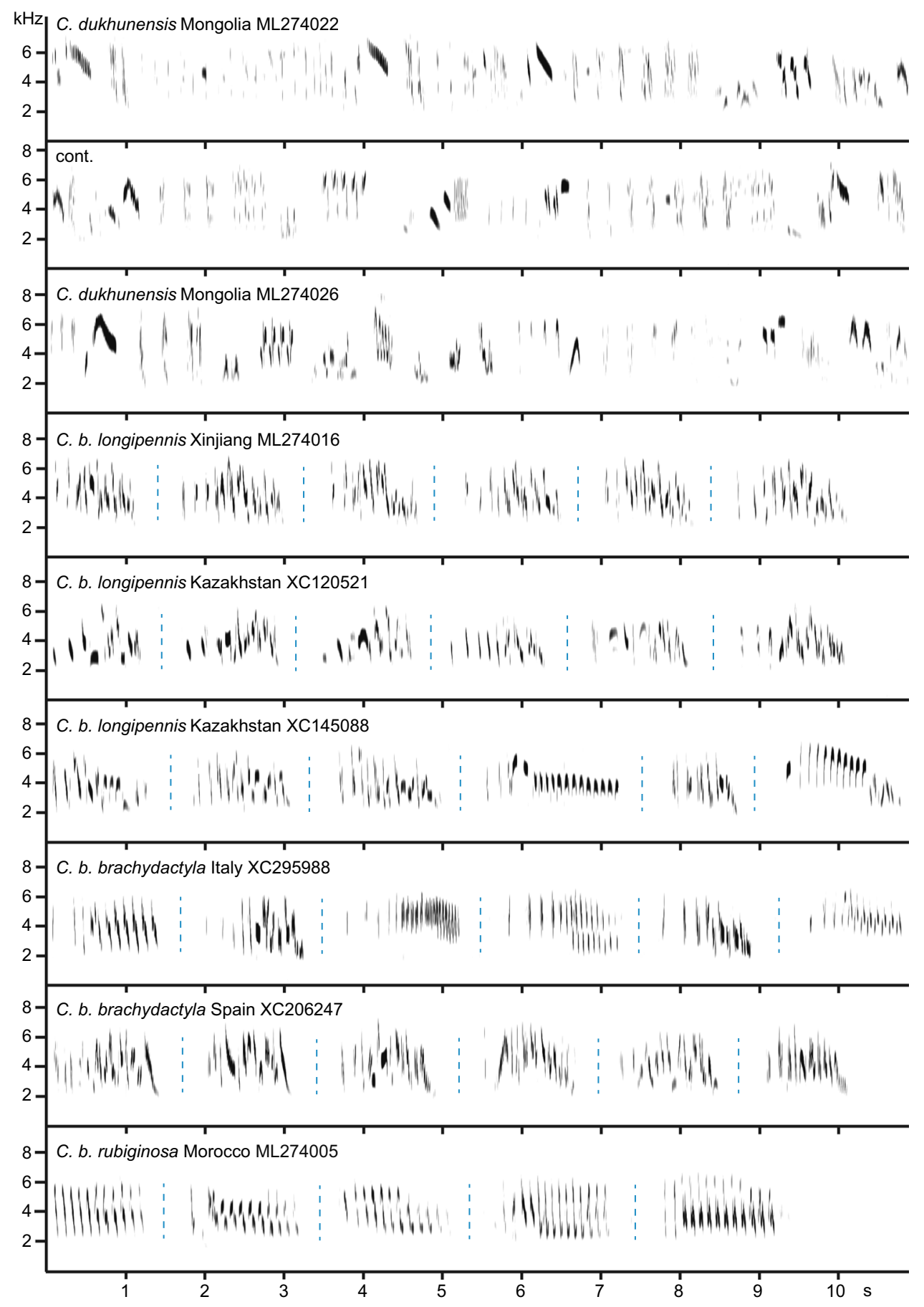

observed $C$. dukhunensis singing from stones and low bushes such as Caragana spp., and displaying on the ground.

Calandrella brachydactyla usually sings in flight, although it sometimes sings also while perched. It should be noted that the song strophes are on average longer and the pauses between the strophes shorter and more irregular when singing while perched or during the ascending part of the song-flight than when at the peak of the song-flight (all of our measurements are from the peak part). The song may also include mimicry while perched or, slightly less frequently, during the ascent, but we have not heard that during the peak of the song-flight. Drawn-out whistles are also frequently given, either singly between strophes or two or more in succession. The song-flight of $C$. brachydactyla begins as in $C$. dukhunensis, but when the peak has been reached and the song changes to 'high flight-song', the wings are intermittently fully closed for a split second causing the flight path to become markedly undulating, and while the 


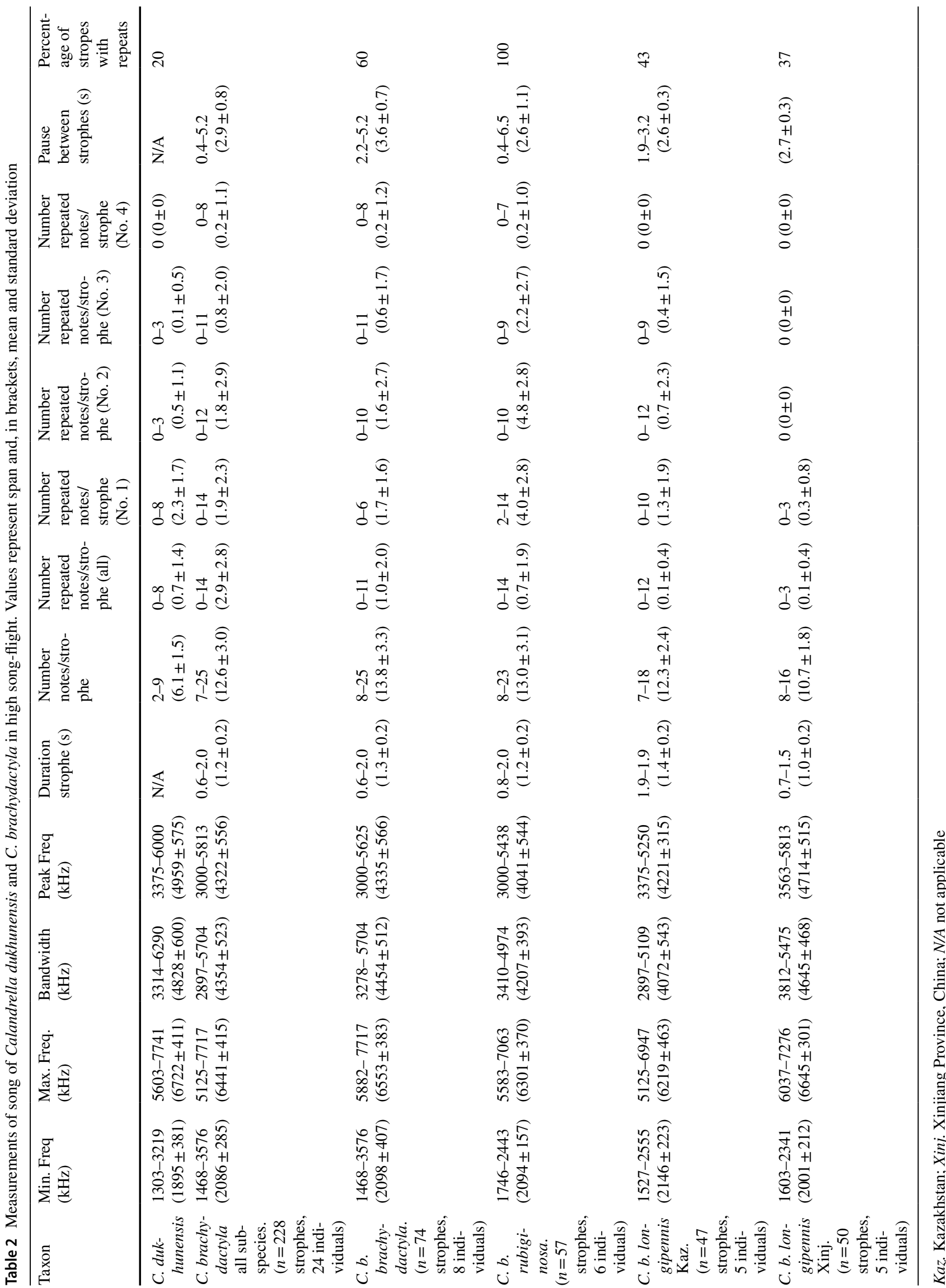


song is delivered the bird glides briefly on extended wings (video of one song-flight, from Xinjiang, viewable at https ://www.macaulaylibrary.org ML488775).

\section{Call}

We have noted several different calls from $C$. dukhunensis. During migration, the commonest contact calls in flight consist of fast, bouncing series, e.g., heu-du-du-du or tru$d u-d u-d u-d u$ (Fig. 7a, b, c). Also, a single or repeated trup or chup (Fig. 7d, e), and a short soft heu (Fig. 7f). Most of these calls are markedly different from the corresponding calls of $C$. brachydactyla, which are short, dry trrep; trrip; trriep; trre-dip, or similar, often two or more given in quick succession, e.g. trrep-trrip or tre-tre-trrep (Fig. 8a, c-f). It also frequently gives a short soft heu (Fig. 8b), which sounds identical to the corresponding call of $C$. dukhunensis; this call may be given singly or doubled, but more commonly combined with the usual flight-call, e.g. trrp heu or heu trriep (Fig. 8b, c).

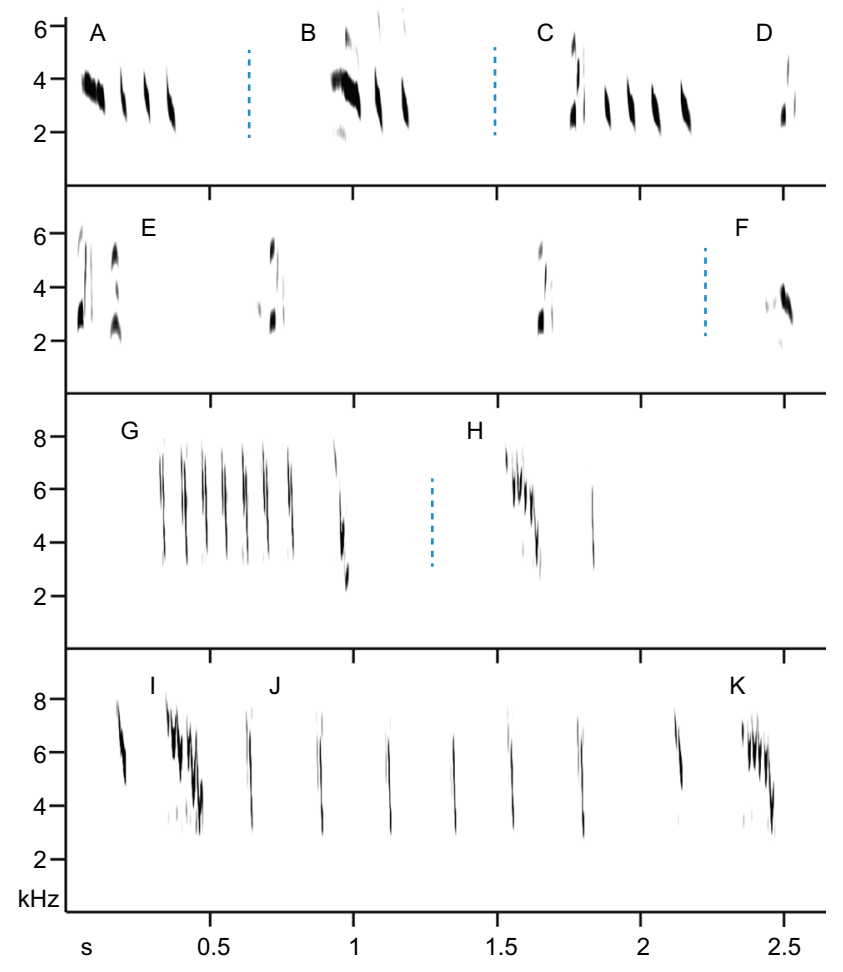

Fig. 7 Calls of Calandrella dukhunensis. Contact calls in flight, Dali, Yunnan Province, China, 31 March 1987 (a, d ML274029; b, c ML274031; e, f ML274030; somewhat uncertain of number of individuals, possibly three different birds). Alarm calls in flight, Hentii Aimag, Mongolia, 18 June 2016 (g-k; ML274028; all from same individual). Blue vertical dotted lines separate different bursts of sounds; letters are referred to in the main text. All recordings Per Alström (colour figure online)

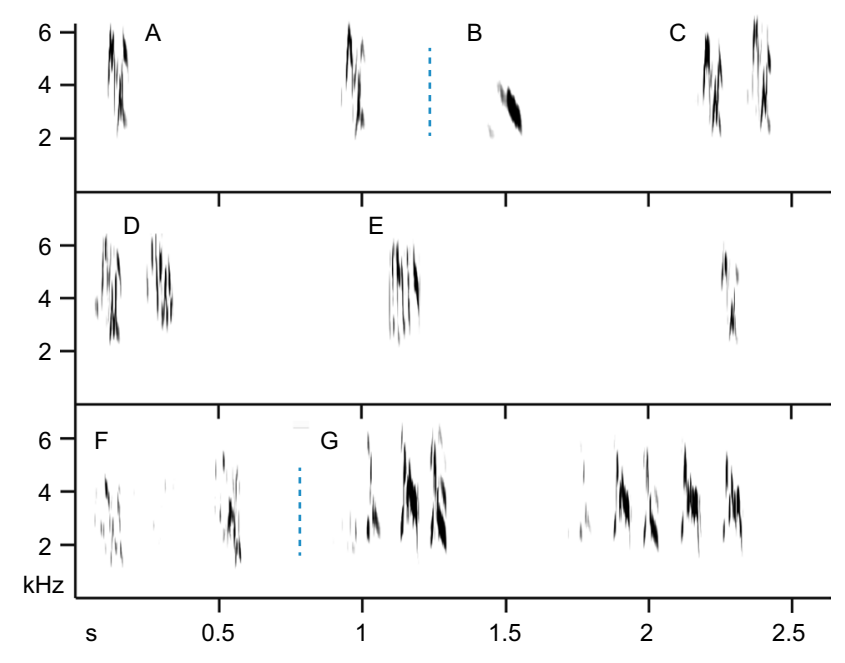

Fig. 8 Calls of C. brachydactyla. Contact calls in flight: C. b. rubiginosa, Morocco, April April 1989 (a ML274007; b, c ML274008; d, e ML274006; all different individuals; Per Alström); C. b. longipennis, Gujarat, India, late January (f XC166341; Frank Lambert). Alarm calls in flight: C. b. longipennis, Kazakhstan, May 2006 (g ML274013; Per Alström). Blue vertical dotted lines separate different bursts of sounds; letters are referred to in the main text (colour figure online)

When alarmed on the breeding grounds, such as near the nest, $C$. dukhunensis gives rattles of hard clicks at different speed (Fig. $7 \mathrm{~g}, \mathrm{j}$ ) as well as sometimes short shrill, harsh whistled tzrriep (Fig. 7h, i, k). The alarm calls of $C$. brachy$d c t y l a$ are reminiscent of its usual contact calls, but are more complex and generally more explosive and harsher (Fig. 8g). Rather shrill whistles are also given. Both species give various short, nasal metallic calls when in flocks on migration and in winter quarters.

\section{Breeding distribution and migration}

We have observed $C$. dukhunensis during the breeding season at 11 localities in the eastern half of Mongolia, from c. $103^{\circ} \mathrm{E}$ to near the easternmost tip of the country (Fig. 9). In addition, we have located 13 specimens from at least 6 localities in Mongolia in different museum collections, also from this region (Fig. 9, Supplementary Table S2; some of the specimens lack detailed locality data). Our only field observation from China during the likely breeding season (late May to July) is of a single individual at the Gegentala grasslands north of Hohhot, Nei Menggu (Inner Mongolia) Province on 27 May, though it showed no evidence of breeding. However, we have examined photographs of specimens from two areas in Nei Menggu Province, China, near the border with Mongolia between 20 April and 27 August and of live birds from one locality in Liaoning Province, China 


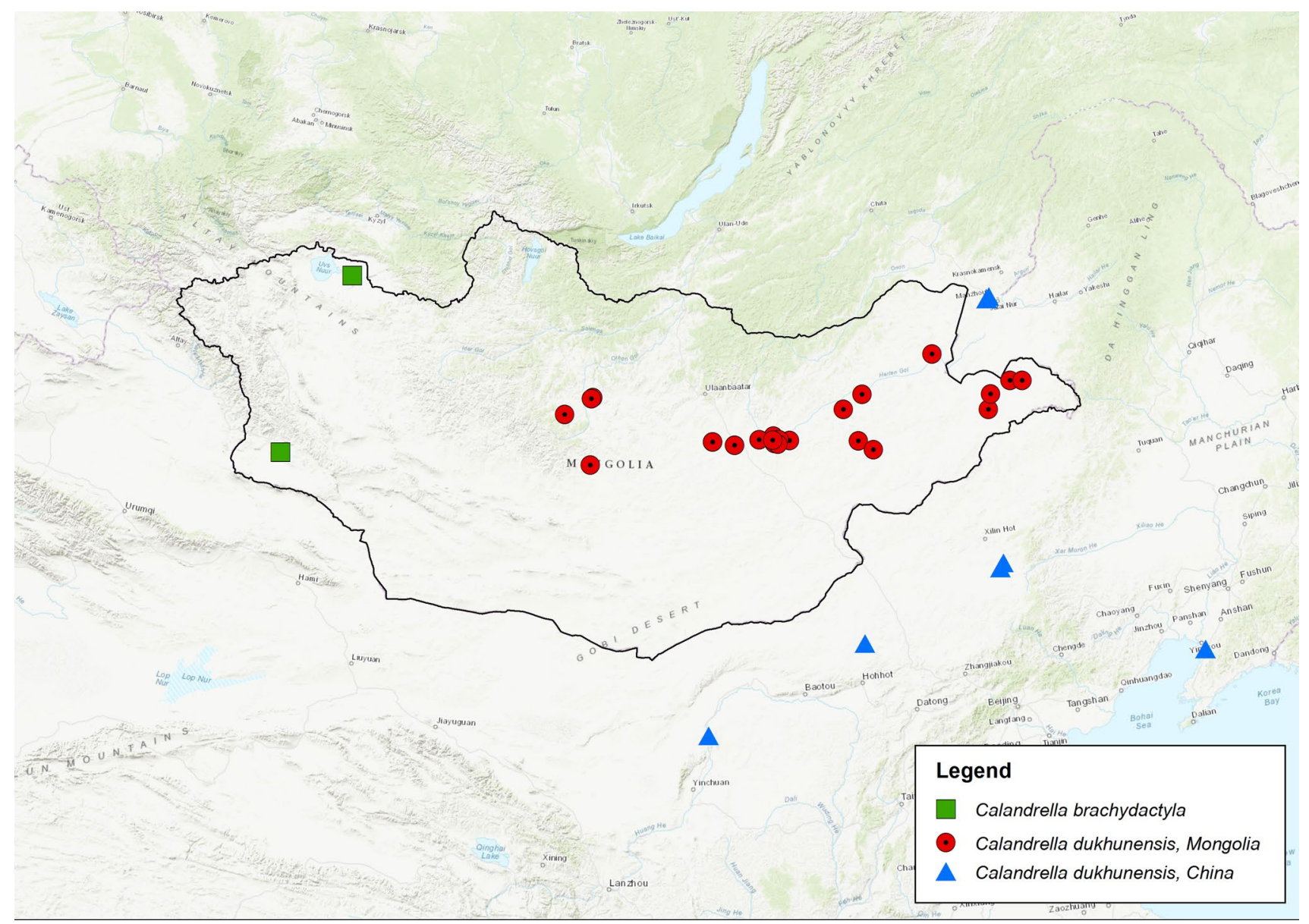

Fig. 9 Confirmed breeding period records of Calandrella dukhunensis (generally late May to late August; records of flocks obviously on migration through north central China in late August have been omitted) and of $C$. brachydactyla from Mongolia. Note that all of the

on 3 June (Fig. 3a, Supplementary Table S2). We have not examined any birds from Russia.

In the non-breeding season, we have seen large flocks of $C$. dukhunensis within the breeding area in Mongolia on 20 August. In China, we have observed flocks on migration in south Xizang (Tibet, mid-April), north Qinghai (c. 20-30 August), west Yunnan (late March/early April and mid-May) and Hebei Provinces (April and mid-May), and Beijing (April). There are specimens from Qinghai Province, China between 29 Aug and 5 Oct in the National Zoological Museum of China, Chinese Academy of Sciences, Beijing (Peng He in litt.), and Paul Holt (in litt.) has observed it in Qinghai as late as 12 October. Calandrella dukhunensis is considered an erratic, usually scarce passage migrant in the Beijing area from early April to early May, peaking in midApril (top numbers 1775 on 17 April 2006 and 1250 on 9 April 2011; Jesper Hornskov, communicated by Paul Holt and Terry Townshend), and, in much lower numbers, c. 20 August to c. 20 October (Paul Holt and Terry Townshend in
Chinese records might refer to birds on migration (20 April to 2 May [type series of $C$. cinerea puii $=C$. dukhunensis], 27 May to 3 June, and 21-27 August), and none of these are known to have been territorial. See Supplementary Table S2 for details

litt.). November and December records from the Beijing area are 'undocumented and probably erroneous' (Paul Holt in litt.). In other words, $C$. dukhunensis probably winters only in the Indian Subcontinent.

\section{Habitat}

In Mongolia, in the breeding season, we have found $C$. dukhunensis in open dry sandy steppe with somewhat sparse short grass (Leymus spp., Stipa spp.), Carex spp., and low herbs (e.g. Artemisia spp.), and often scattered low bushes (e.g. Caragana spp.), sometimes taller grass (e.g. Achnatherum splendens). There appears to be a preference for reddish-brown or sandy soil with the vegetation dominated by Leymus chinensis, Caragana stenophylla and Carex duriuscula in east Mongolia; Stipa krylovii, Achnatherum splendens and Caragana stenophylla in the Darkhan area, Hentii Province; and Stipa krylovii, Carex 
sp. and Caragana leucophloea near Ugii Lake, Arkhangai Province. See Fig. $4 \mathrm{e}-\mathrm{f}$ for examples of the habitat of $C$. dukhunensis.

After breeding, dispersed young birds and adults stay along the wide open valleys of large rivers and surrounding areas of small to large lakes in the steppe. They select habitats with open water, abundant seeds, and areas with tall grasses like Achnatherum splendens. Up to $600+$ individuals have been observed in a day. On migration in Mongolia, they occur in various open habitats with abundant seedy plants with water resources, from mountain steppe to desert steppe. Large rivers, ponds and various sized lakes in the steppe and desert steppe attract many migrating individuals.

We have not noted any differences in habitat choice between $C$. dukhunensis and C. brachydactyla. However, C. dukhunensis is apparently rather specific in its habitat choice, as it is locally common, yet missing from seemingly suitable habitats within its known range.

\section{Breeding}

Breeding begins in the Middle Khalkh steppe in Mongolia in early May. The first full clutch (with already well incubated eggs) has been found on 23 May in the Darkhan area, Mongolia. The nest is built on the ground underneath clumps of tall grass like Achnatherum splendens and bushes like Caragana spp.. The dense vegetation protects the nest from strong wind and hides it from predators. Out of all nests found $(n=14), 71.4 \%$ were found underneath Achnatherum splendens, with $14.3 \%$ under Caragana spp. bushes, $7.2 \%$ underneath Carex spp., and 7.1\% underneath cow dung. The nest consisted of dried stems of plants such as Carex spp. and Stipa spp. and were lined with very thin and fine dried grasses and some hairs. The mean clutch size was $3.4(n=17)$. The size of the eggs was $20.4 \mathrm{~mm}$ $(\mathrm{SE}=0.14, n=18) \times 14.9 \mathrm{~mm}(\mathrm{SE}=0.06, n=18)$, and the weight $2.49 \mathrm{~g}(\mathrm{SE}=0.09, n=7)$. In mid-June in the Middle Khalkh steppe, most nests had a full clutch, and in late June, we observed freshly laid eggs in a nest in east Mongolia. We have observed recently fledged young in mid-to late June. It seems highly likely that the species has two broods. See Fig. $4 \mathrm{c}$ and $\mathrm{d}$ for photos of the nest, with eggs and young.

\section{Discussion}

\section{Taxonomy}

Our data corroborate the previously published molecular data that suggest that $C$. dukhunensis should be treated as a separate species from C. brachydactyla sensu stricto (s.s.). The songs and calls differ strongly between these two species, and they also have somewhat different song-flights. The morphological differences between them are slight, although the wing- and tail lengths are significantly different. In view of the rather pronounced plumage variation within $C$. brachydactyla s.s., often at a very local scale, likely as a result of 'soil matching' (cf. Donald et al. 2017), the morphological differences are of limited taxonomic value. However, it is interesting to note that $C$. dukhunensis has a partial pre-breeding moult of similar extent to its sister species, C. acutirostris (P.A., pers. obs.), unlike C. brachydactyla, which usually has no pre-breeding moult. Shirihai and Svensson (2018) note that $C$. dukhunensis has a proportionately deeper bill than $C$. brachydactyla (we lack own measurements of bill depth).

Calandrella cinerea puii was described based on a sample of 8 males and 2 females collected at 'Lamagulusu, Manchuria' ('10 km. southeast from the shore of Lake Dalainor', i.e. Dali Nur, Nei Menggu Province., China) on 20 April to 2 May 1935 (housed in the Yamashina Institute for Ornithology; holotype available at https://decochan.net/index $. p h p ? p=2 \& o=s s p \& i d=59716)$. Although not explicitly stated, based on the distribution given in Christidis (2018), Clements et al. (2019) and Gill et al. (2020), this taxon was synonymised with $C . b$. orientalis by the first and third authors and with $C$. b. longipennis by the second author (C. b. orientalis was apparently synonymised with $C . b$. longipennis by the second author). Shirihai and Svensson (2018) explicitly synonymise puii with dukhunensis.

Calandrella cinerea puii is said to differ from dukhunensis by its 'paler colour of under surface and under tailcoverts' (Yamashina 1939). We have directly compared two topotypical specimens (collected on 30 April) with three specimens of dukhunensis (from north-eastern India, southeastern Tibet, and north central China, from late March to mid-April) and seven specimens of longipennis (from Pakistan and Iran in late March). One of these puii matches $d u k$ hunensis perfectly, except that the central part of the breast is paler. The other puii is paler on the breast than the first one, though some feathers on the side of the breast match $d u k$ hunensis in colour and are more deeply coloured than in any of the seven longipennis. Yoshimitsu Shigeta (in litt.) has compared all 14 specimens of puii (including the entire type series) in the Yamashina Institute for Ornithology with $3 C$. b. hermonensis and 1 C. b. brachydactyla, and he remarks that puii is darker on the breast-sides than all these, which speaks against longipennis. Moreover, the 2 puii specimens that were examined by us had replaced 1-3 tertials, which is more in agreement with $C$. dukhunensis than with $C$. brachydactyla. Based on these observations, we consider puii to be a synonym of $C$. dukhunensis, and therefore, that the easternmost limit of the range of $C$. brachydactlya lies in extreme western Mongolia. 


\section{Distribution of Calandrella dukhunensis}

It is clear that $C$. dukhunensis breeds chiefly in the east half of Mongolia. We suggest that it only breeds locally in China, in Nei Menggu Province and probably also in Liaoning Province. The type series of puii was collected in the south central part of Nei Menggu Province on 20 April-2 May. This is likely near the peak of the migration in this area. However, there is one specimen in the NZMC-IOZ from further west in Nei Menggu from 27 May (Supplementary Table S2), which seems on the late side for a migrant, as does our own observation from south Nei Menggu on the same date (Supplementary Table S2). Cheng (1987) states that dukhunensis breeds at 'Hulun Buir L.' (lake) in the northernmost part of Nei Menggu, China, neighbouring northeastmost Mongolia, which seems reasonable.

We doubt that $C$. dukhunensis breeds on the Tibetan Plateau, including Gansu, Qinghai, Sichuan, Yunnan and Xizang (Tibet) Provinces, contrary to what has been widely claimed (e.g. Vaurie 1951, 1959; Peters 1960; Vaurie 1972; Meyer de Schauensee 1984; Glutz von Blotzheim and Bauer 1985; Cheng 1987; Cramp 1988; Christidis 2018; Shirihai and Svensson 2018; Clements et al. 2019; Gill et al. 2020; de Juana and Suárez 2004; del Hoyo and Collar 2016; del Hoyo et al. 2020). We consider this to be a widespread misconception, which is based on migrant $C$. dukhunensis or breeding C. acutirostris (e.g., all breeding period specimens from the Tibetan Plateau in the NZMC-IOZ originally identified as C. 'cinerea', i.e. C. dukhunensis, are C. acutirostris; Peng He in litt.).

Calandrella brachydactyla sensu lato is usually considered to breed across Mongolia (e.g. Vaurie 1951; de Juana and Suárez 2004; Gombobaatar et al. 2011). In the western part of the country, it is considered to occur in the Great Lakes Depression, Mongol-Altai Mountain Range, and Baruun Khurai Depression (Tugarinov 1929; Kozlova 1930; Bold 1973; Bold and Tseveenmyadag 1982; Fomin and Bold 1991; Dawaa et al. 1994; Gombobaatar et al. 2011). However, none of these references provide sufficient detail to verify the occurrence of $C$. brachydactyla sensu stricto in Mongolia. It seems quite likely that it breeds in west Mongolia based on the fact that it breeds nearby in Kazakhstan and Xinjiang. However, the only evidence of occurrence in west Mongolia that we have seen is a specimen from Bodoncijn-gol in the Altay region (Zentralmagazin Naturwissenschaftlicher Sammlungen, Martin-LutherUniversität Halle-Wittenberg IZH-V 0701 Sammel-Nr.: MVR 1962/763). Accordingly, based on current evidence, it appears that $C$. dukhunensis and $C$. brachydactyla are rather widely allopatric in the breeding season. Further field surveys are critical to understand the distributions of the two species in Mongolia.
According to del Hoyo et al. (2020), C. dukhunensis winters in the southern half of India and northeast China. Although we have not studied the winter distribution of this species in detail, it is clear that it winters in India, mainly south and east of $C$. brachydactyla (which occurs chiefly in the northwestern part of the Indian Subcontinent, and then further west). However, we have not found any evidence that C. dukhunensis winters in China (or elsewhere in Southeast Asia).

\section{Song of Calandrella brachydactyla}

The pronounced west to east decline within $C$. brachydactyla in the proportion of song strophes with repeated notes has not been noted before, with $C$. b. rubiginosa from Morocco standing out. Stervander et al. (2016) found no divergence in mitochondrial cytochrome $b$ between samples from Morocco, Tunisia, Spain, France, Italy, Hungary, Croatia and Greece (one sample), and only very shallow divergence between these and samples from Greece (one sample), Turkey, Georgia, Lebanon, Iran, Kazakhstan, Uzbekistan, Afghanistan and India (winter). It seems, therefore, that the pronounced geographical variation in song structure revealed here represents local variation and is not indicative of cryptic speciation.

\section{Conclusion}

Our studies of, especially, the vocalisations and song-flight of $C$. dukhunensis support the treatment of this taxon as a distinct species. We show that its breeding distribution is considerably smaller than previously reported in the literature, and is almost certainly restricted to the eastern half of Mongolia and marginally neighbouring parts of China and perhaps Russia. In addition, we present new data on various aspects of its biology. As the distribution of this taxon has long been misinterpreted, several studies, e.g. of its breeding biology in Tibet (see del Hoyo et al. 2020), almost certainly refer to C. acutirostris.

Acknowledgements We are grateful to the following persons and institutions for information on specimens in their collections, or for granting access to their collections: Hans Altner and Frank Steinheimer/ Zentralmagazin Naturwissenschaftlicher Sammlungen, Martin-LutherUniversität Halle-Wittenberg; Rüdiger Becker/Museum Heineanum; Pascal Eckhoff/Museum für Naturkunde Berlin; Jon Fjeldså and Jan Bolding Kristensen/University of Copenhagen Zoological Museum; Janet Hinshaw/University of Michigan Museum of Zoology; Heng Pe/ National Zoological Museum of China, Chinese Academy of Sciences; Albrecht Manegold/Staatliches Museum für Naturkunde Karlsruhe; Martin Päckert/Museum für Tierkunde, Senckenberg Naturhistorische Sammlungen Dresden; Soronzonbold Ochirvaani/ Natural History Museum, Mongolia; Davaasuren Punsalpaamuu/National University of Mongolia and Mongolian Ornithological Society; Robert Prys-Jones, 
Mark Adams and Hein van Grouw/The Natural History Museum; Manuel Schweizer/Naturhistorisches Museum Bern; Paul Sweet/ American Museum of Natural History; Thomas Tietze/Centrum für Naturkunde, Universität Hamburg; Takema Saitoh and Yoshimitsu Shigeta/Yamashina Institute for Ornithology; and Friederike Woog/ Staatliches Museum für Naturkunde Stuttgart for information on specimens; to Chengyi Liu, Paul Holt, Jonathan Martinez, Eloisa Matheu and Terry Townshend for information on field observations, photos and/or sound recordings; to Matthew Medler at the Macaulay Library for quickly providing accession numbers to new recordings deposited there; and to Paul F. Donald for comments on the manuscript and for the use of a photo. We would like to express our thanks to Dr. Ts. Amartainan, head of the Division of School of Natural Sciences, National University of Mongolia and MSc. Yumjirmaa Bayarmagnai, secretary of the Mongolian Ornithological Society for their support with logistics and official documents for field work in Mongolia, and to Jornvall Foundation for support. Claus Rüffler kindly translated the abstract into German.

Funding Open access funding provided by Uppsala University.

Open Access This article is licensed under a Creative Commons Attribution 4.0 International License, which permits use, sharing, adaptation, distribution and reproduction in any medium or format, as long as you give appropriate credit to the original author(s) and the source, provide a link to the Creative Commons licence, and indicate if changes were made. The images or other third party material in this article are included in the article's Creative Commons licence, unless indicated otherwise in a credit line to the material. If material is not included in the article's Creative Commons licence and your intended use is not permitted by statutory regulation or exceeds the permitted use, you will need to obtain permission directly from the copyright holder. To view a copy of this licence, visit http://creativecommons.org/licenses/by/4.0/.

\section{References}

Alström P, Barnes KN, Olsson U, Barker FK, Bloomer P, Khan AA, Qureshi MA, Guillaumet A, Crochet P-A, Ryan PG (2013) Multilocus phylogeny of the avian family Alaudidae (larks) reveals complex morphological evolution, non-monophyletic genera and hidden species diversity. Mol Phylogenet Evol 69:1043-1056. https://doi.org/10.1016/j.ympev.2013.06.005

Bold A (1973) Birds of Mongolia. In: Scientific Proceedings of the Biological Institue of the Mongolian Academy of Sciences, pp. 139-166. (In Mongolian)

Bold A, Tseveenmyadag (1982) Birds of the Great Gobi SPA, Mongolia. Problems on the conservation of Gobi Ecosystems. Ulaanbaatar, Mongolia. pp. 109-156. (In Mongolian)

Cheng T-H (1987) A synopsis of the avifauna of China. Science Press, Beijing

Christidis L (2018) The Howard and Moore complete checklist of the birds of the world, version 4.1 (Downloadable checklist). https:// www.howardandmoore.org. Accessed 1 April 2020

Clements JF, Schulenberg TS, Iliff MJ, Billerman SM, Fredericks TA, Sullivan BL, Wood CL (2019) The eBird/clements checklist of birds of the world: v2019. Downloaded from https://www.birds .cornell.edu/clementschecklist/download/

Colston PR, Shirihai H (1986) The first example of the rufous Shorttoed Lark (Calandrella brachydactyla dukhunensis) for the Western Palearctic, from the Negev Desert, Israel. Sandgrouse 7:62-63

Cramp S (ed) (1988) The birds of the Western palearctic. Oxford University Press, Oxford
Dawaa N, Busching WD, Sumijaa D, Bold A, Samijaa R (1994) Checklist of Birds and Mammals. Naumann-Museum Köthen, Vögel (in German and Mongolian)

de Juana E, Suárez F (2004) Greater Short-toed Lark (Calandrella brachydactyla). In: del Hoyo J, Elliott A, Sargatal J, Christie DA, de Juana E (eds) Handbook of the Birds of the World. Lynx Edicions, Barcelona, p 583

del Hoyo J, Collar NJ (2016) HBW and birdlife international illustrated checklist of the birds of the world. Lynx Edicions, Barcelona

del Hoyo J, Collar N, Kirwan GM (2020) Eastern Short-toed Lark (Calandrella dukhunensis). In: del Hoyo J, Elliott A, Sargatal J, Christie DA, de Juana E (eds) Handbook of the Birds of the World Alive. Lynx Edicions, Barcelona

Dickinson EC, Christidis L (eds) (2014) The Howard and Moore complete checklist of the birds of the world. Aves Press, Eastbourne

Donald P, Alström P, Engelbrecht D (2017) Possible mechanisms of substrate colour-matching in larks (Alaudidae) and their taxonomic implications. Ibis 159:699-702. https://doi.org/10.1111/ ibi. 12487

Fomin VE, Bold A (1991) Catalogue of the birds of the Mongolian People's Republic. Moscow. Nauka, p. 124. (in Russian)

Gill F, Donsker D, Rasmussen P (Eds) (2020) IOC World Bird List (v10.1). https://doi.org/10.14344/IOC.ML.10.1

Glutz von Blotzheim UN, Bauer KM (eds) (1985) Handbuch der Vögel Mitteleuropas. Band 10. Aula-Verlag, Wiesbaden

Gombobaatar S, Monks EM, Seidler R, Sumiya D, Tseveenmyadag N, Bayarkhuu S, Baillie JEM, Boldbaatar S, Uuganbayar C (2011) Regional red list series birds. Zoological Society of London, National University of Mongolia, and Mongolian Ornithological Society, Ulaanbaatar

Hollom PAD, Porter RF, Christensen S, Willis I (1988) Birds of the Middle East and North Africa. Calton.

Kozlova EV (1930) Birds of South-Western Baikal, Northern Mongolia and Central Gobi. Moscow. Nauka, p. 7-361. (In Russian)

Meinertzhagen R (1951) A review of the Alaudidae. Proc Zool Soc Lond 121:81-132

Meyer de Schauensee R (1984) The birds of China. Washington, D.C.

Peters JL (1960) Family Alaudidae. In: Mayr E, Greenway JC (eds) Check-list of birds of the world. Museum of Comparative Zoology, Cambridge, pp 3-80

Porter RF, Christensen S, Schiermacker-Hansen P (1996) Field guide to the birds of the Middle East. London.

Shirihai H, Svensson L (2018) Handbook of Western palearctic Birds, vol 1. Helm, Bloomsbury

Sibley CG, Monroe BL (1990) Distribution and taxonomy of birds of the world. New Haven.

Stervander M, Alström P, Olsson U, Ottosson U, Hansson B, Bensch S (2016) Multiple instances of paraphyletic species and cryptic taxa revealed by mitochondrial and nuclear RAD data for Calandrella larks (Aves: Alaudidae). Mol Phylogenet Evol 102:233-245. https ://doi.org/10.1016/j.ympev.2016.05.032

Tugarinov AY (1929) North Mongolia and birds of the country. In: Proceedings of Research in Mongolian and Tuva Republic. V. 3. Leningrad. pp. 10-236 (In Russian).

Vaurie C (1951) A study of Asiatic larks. Notes from the Walter Koelz collections number 11. Bull Am Mus Nat Hist 97:435-526

Vaurie C (1959) The birds of the palearctic fauna. Passeriformes. H. F. \& G Witherby Publications, London

Vaurie C (1972) Tibet and its birds. H. F. \& G Witherby Publications, London

Yamashina Y (1939) Notes on the specimens of Manchurian birds chiefly made by Mr. Hyojiro Orii in 1935 . Tori 10:446-545

Publisher's Note Springer Nature remains neutral with regard to jurisdictional claims in published maps and institutional affiliations. 